\title{
GUARDIANSHIP FOR MENTALLY RETARDED ADULTS: RECOMMENDATIONS FOR LAW REFORM
}

\author{
GAIL CZUKAR \\ University of Toronto
}

\begin{abstract}
As increasing numbers of mentally retarded people move from institutions to community living, adequate provision must be made for some form of legal guardianship. Existing guardianship laws have been criticized for being inflexible and for emphasizing property management at the expense of personal support. The guardian's crucial role should be to promote the best interests of the retarded individual while also respecting his her personal preferences. Principles to guide guardian decision-making are discussed in this context, including issues of values and priorities. Some of the reforms necessary to achieve a balanced guardianship program include the development of clearly defined guidelines for imposition of guardianship: provision for guardian accountability, and basic procedural fairness.
\end{abstract}

\section{INTRODUCTION}

Over the past two decades, the lack of adequate legal provision for personal guardianship for mentally retarded adults has increasingly become a concern for parents, providers of service, and advocates (International League of Societies for the Mentally Handicapped, 1969; United Nations, 1971; Ontario Association for the Mentally Retarded, 1980; McLaughlin, 1979), Par-

1. The author holds an M.A. degree in Psychology and Was a community development worker both with the Ontario Association for the Mentally Retarded and Mental Health, Ontario. Ms. Czukar is currently a third year student, Faculty of Law, University of Toronto.

\section{Acknowledgements}

I wish to express my appreciation to the Scottish Rite of Canada which heiped support my second year of studies at the Faculty of Law through their Bursary Program administered by the National Institute on Mental Retardation. Sincere thanks are also due to Dr. Bernard Dickens for his comments and his encouragement to publish this paper. ents have always asked "What will happen to our mentally handicapped child (who is now an adult) when we are gone?", but the query has taken on new meaning as more and more mentally retarded people outlive their parents and take on independent or assisted community living.

All provincial governments have been pursuing programs of deinstitutionalization and development of community-based services since the early 1970 s, with the result that many retarded persons previously denied training programs, educational opportunities, and normal life experiences now have the chance to succeed on their own in the community with the aid of various support systems. But many others do not yet possess the skills and knowledge requisite to independent community living, and still others may never achieve total self-reliance.

It is argued by parents, professionals, and advocates that the handicapped individual requires the protection and guidance of a legally-empowered advocate to ensure that 
the retarded person's rights to services and fair treatment are fully exercised, and to protect him/her from abuse and neglect at the hands of unscrupulous landlords and salespeople, institutional or community service providers, and evn their own families.

Whether the legal system is the most appropriate vehicle for achieving these ends is a matter of some debate (McLaughlin, 1979; Vickers, 1980). The law is rarely used to promote a preferred lifestyle, although protection from abuse and neglect has certainly been made the subject of various laws. In the case of guardianship for mentally retarded adults, the legal issues are slightly different.

Choices in matters of residence, work, socializing, marriage, child-bearing, property acquisition and disposition, and medical treatment usually involve legal transactions such as making contracts, lease agreements, consents to medical procedures, and others. Where a person does not possess the intellectual capacity to make informed judgments, others may refuse to deal with him/her or may take advantage of the person's weaker bargaining position. While the law may, in some cases, provide relief on grounds of unconscionability, this protection may be inadequate in many situations involving retarded persons. Alternate provision must be made for substitute decision-making to enable the person who lacks mental capacity to carry on his/her life.

Parents have historically acted as ad hoc guardians for their adult mentally handicapped offspring, and institutional administrators have exercised guardian-like decision-making powers in the absence of parental involvement. However, the assumption of total decision-making power by another person seriously undermines a person's growth toward self-sufficiency. Thus, the appointment of a legal guardian essentially defeats the main goal of communitybased programming. In addition, neither parents nor professional caregivers have legal authority to make decisions for adults over 18 unless they have been appointed ats guardians according to the prescribed statutory procedure.

The purposes of this article are both to analyze the legal principles which should underlie the role of the guardian and to pre. sent recommendations for change in Ontario's guardianship law. Although Ontario's Mental Incompetency Act (R.S.O. 1980, c. 264) is used here for discussion purposes, all other Canadian jurisdictions, except Alberta, have statutes with similar provisions to which the suggestions made here would readily apply. With its Dependent Adults Act (S.A. 1976, c. 63 as am.), Alberta became the first Canadian province to initiate a public, partial guardianship program.

The term "mental incompetency" can be confusing and misleading. It may refer to "legal or factual incapacity, either of which may be temporary or permanent" (Sommerville, 1979 , p. 89). However, the term is used in The Mental Incompetency Act, and will be used in this article, only to refer to a legal status as conferred by a court following the procedures set out in the Act. The reader should guard against assuming that legal incompetence necessarily coincides with factual incompetence, even though the statutes do frequently make this assumption. A common criticism of guardianship laws is that they do not accurately reflect people's capabilities and needs, nor do they distinguish among varying levels or types of competence. In the absence of more clearly defined language, this author will use "mental incompetency" in the legal sense, and other terms such as "mental incapacity" to describe the fact of a person's disability.

A brief overview of Ontario's Mental Incompetency Act will illustrate the court procedures and legal elements of the current guardian appointment process. The scant Canadian case law on guardianship will also be covered.

Ontario's Mental Incompetency Act, R.S.O. 1980 , c. 264 : 
A mentally incompetent person is defined as one

(i) in whom there is such a condition of arrested or incomplete development of mind, whether arising from inherent causes or induced by disease or injury, or

(ii) who is suffering from such a disorder of the mind, that he requires the care, supervision and control for his protection and the protection of his property. (s.1 (e)).

An application for a declaration of mental incompetency may be made by anyone, including the Attorney-General, next-of-kin, or a creditor ( $\$ .7(2))$. It must be supported by affidavits from two medical practitioners and a family member or friend who can testify to the incompetency (Weir, 1963). A county, district or Supreme Court (the latter at the respondent's request) must be satisfied beyond a reasonable doubt to make a declaration of incompetency (s. 7 (1)). Where the evidence does not establish incompetency beyond a reasonable doubt, or for any other reason, the court may direct a trial. (s. $8(1))$ which can be by jury at the alleged incompetent's notice ( $5.8(2)$ and s. 9). The person who is the subject of the application may attend, but the judge may dispense with his/her production or examination (s. 8 (4)). There are no requirements as to who must be notified of the proceedings.

Following a declaration of incompetence under section 7 (and presumably also under s. 8 , although the Act is silent on this), or a declaration that the person is incapable of managing his/her affairs ( $s, 39)$, the court must appoint a committee of the person, or of the estate, or both ( $5,12(1)(\mathrm{a}))$. Where a committee of the estate is appointed, a scheme for its management must be propounded and a date fixed for the passing of accounts (s. $12(1))$. This order must be affirmed by the Supreme Court (s. 12 (2)). The committee's duties are described solely in terms of estate management (s. 13), and Sections 14 to 38 are concerned with the management and administration of the estate.

Section 11 describes the procedure for reversing an incompetency declaration, and appeals by the incompetent person or anyone affected by the order are allowed in accordance with the rules of the court (ss. 7 (3) \& (4), 8 (7), \& 39 (5)).

\section{CASE LAW}

Case law on guardianship in Ontario, indeed in Canada, is sparse. Only two principles can be said to have been settled at common law, Re McLaughlin, [1905] A.C. 343 , an English case adopted by the Supreme Court of Canada in Wright v. Wright, [1951] S.C.R. 728, held that the jurisdiction over guardianship of estates exists for the benefit of the mentally handicapped person, and that the guiding principle must be what is most for the benefit of the alleged incompetent person. Whether this standard amounts to an objective "best interests" test is not clear from that case, nor from subsequent jurisprudence. An Ontario case, Re Avery, [1951] O.W.N. 810, held that the subject of the application is entitled to due process of law:

We must remember that is cases of this kind we are dealing with the liberty of the subject, and it is fundamental to our law that no person is to be deprived of his liberty without due process of law. (Re Avery, at 811).

However, this statement must be qualified by the holding in Wright, which was decided in the same year as Re Avery, that due process of law does not necessarily include the right to notice of the application where the judge is of the opinion that personal service would be harmful to the respondent. It is questionable that such a paternalistic attitude would be upheld by most courts today. Also, legal aid now eases the appointment of lawyers to protect the interests of incompetents. 


\section{WHY CHANGE IS NEEDED IN GUARDIANSHIP LAW:}

Guardianship law is firmly rooted in feudalism, having evolved from a 14th century English statute. Many contemporary guardianship or conservatorshiplaws are criticized for retaining a primary emphasis on property management and ignoring the human aspects of the relationship. For example, the Ontario Act makes only two explicit references to personal guardianship, or committeeship, in sections 4 and 12. The remainder of the Act deals with estate management and administration, and it has been used most often to provide for the appointment of the Public Trustee as committee of the estates of institutionalized persons.

Several books and articles have criticized guardianship laws, and it is not possible to review that rather considerable body of literature here. See, for example, McLaughlin (1979), Mitchell (1979), Sherman (1980), Hodgson (1973), Dussault (1978), Vickers (1980), International League (1969). The major faults which are relevant to most Canadian statutes can be summarized briefly as follows:

1. Property management is over-emphasized while personal guardianship needs are ignored.

2. Guardians are not universally available on the basis of need.

3. An inquiry into a person's mental competency is inappropriate as the subject of the legal proceeding in several respects:

- a declaration of mental incompetency is inflexible and excessively intrusive as a means of facilitating the appointment of a guardian.

- the real needs (functional) of the individual may not be investigated;

- vested interests of the applicants may be overlooked;

- there is excessive reliance on medical opinion.

4. Basic procedural safeguards, such as notice and right to representation, are absent.
Other procedural defects have been fully canvassed by Sherman (1980), Mitchel] (1979) and others.

5. A finding of mental incompetency has uncertain effect in terms of the extent of rights lost by the incompetent person, and extent of duties to be assumed by the guardian.

For these reasons and others, there is general agreement among parents, human service workers, and lawyers that the need for reform is great, but a consensus on what changes should be implemented is much less readily attained.

One obvious improvement would be to require that the medical and family opinion evidence meet specific, objectively defined functional criteria which are stated in the Act to determine the person's level of factual competence/incompetence. This would eliminate the need for a global finding of incompetency. The judgment as to whether a guardian is needed, and the extent of the powers to be given to a guardian, could be based on findings made in respect of the functional criteria.

A program of publicly funded guardians is usually proposed as a remedy to the lack of universal availability of guardians on the basis of need. Counter-arguments to this idea include the inevitable conflicts of interests faced by paid professionals in the role of advocate (Wolfensberger, 1977) and the high cost of such a program to the public.

Flexibility and privacy might be increased by providing a means of limiting the guardian's decision-making powers to those matters in which the particular ward has greatest difficulty acting on his/her own, and not granting the guardian authority to make decisions in other areas. On the other hand, some critics regard limited guardianship as another means of instituting social control over people who would otherwise remain free, their privacy inviolate (Mitchell, 1979). A global finding of incompetency bears such serious consequences that it would rarely be made with respect to a 
person who was reasonably able to manage independently, but limited guardianship would give the state a new tool to intervene in that person's life, so the argument runs. The "slippery slope" of control is even more threatening to individual freedom than the all-or-nothing approach of many current statutes.

These fears have been borne out to some extent by experiences in Alberta and Saskatchewan. The Alberta Dependent Adults Act provided for a public, partial guardianship scheme. Only four years after it became operational, amendments were passed providing for compulsory care orders that give authority for any person to confine the dependent adult in a place of care for three years (Dependent Adults Amendment Act, S.A. 1980 , c. $15,5,10$ ). "Place of care" is defined in a Schedule to the Act as one of a number of institutional settings for retarded persons.

The Saskatchewan Law Reform Commission issued a set of proposals for reform of guardianship law shortly before publishing another report recommending increased control within mental health facilities (Law Reform Commission of Saskatchewan, 1981 la \& b). It is clear that the Commissioners saw a continuum of social control and protection in their proposed measures. This is not the sort of continuum that McLaughlin, Wolfensberger or Vickers has in mind. Mitchell (1979) believes these are predictable trends and sounds an ominous note of pessimism:

Reform litigation and legislative revision alone will not alter the underlying public attitudes and ingrained institutional policies that have nurtured reliance on guardianship to serve social welfare ends... Involuntary guardianship has recently been described as a glaring anachronism in a society that values independence and self-determination. Until those values are guaranteed to the less able and the economically dependent, the "right to be let alone" will remain an empty promise for the objects of our benevolent intervention. (p. 1433)

The point at which legitimate protection becomes excessive control is undefinable, as it varies for each individual. Nevertheless, policy must be developed for the collective, not the individual. Consequently, the protection-versus-control issue is at the centre of the guardianship debate:

I become somewhat alarmed when I look closely at some of the people advocating guardianship legislation. While I have not heard any consumer group speak out on the subject, 1 do hear parents, many of whom are incapable themselves of giving up control. More frightening is the argument of some keepers of our institutions who think a guardianship order is appropriate when a patient voluntarily seeks to leave an institution. We must constantly remind ourselves that guardianship legislation does not seek to control, nor is it paternalistic. It seeks to understand and to protect where protection is necessary. (Vickers, 1980, p. 15)

This statement has even more impact when one considers it was mady be the former Assistant Deputy Attorney General of British Columbia, himself the parent of a handicapped person.

A successful guardianship program must be able to respond in a balanced fashion to legitimate protection needs without subordinating the best interests and personal wishes of retarded persons to social welfare ends. The guardian's role will be crucial in achieving this goal.

\section{THE ROLE OF THE GUARDIAN}

A set of principles that defines and guides the guardian's duties without unduly restricting his/her discretion should be incorporated into a guardianship statute. The incentive to always choose the safest, i.e. most conservative, course of action for the 
retarded individual must be removed. Some options considered here include specifying matters in respect of which the guardian can exercise exclusive authority and those which require a court order, creating duties to make choices which will serve the best interests and personal preferences of the retarded person, even where risk is involved; and providing a forum for public discussion of the values by which guardians are expected to make decisions and resolve conflicting choices.

The following discussion draws extensively from the Alberta Dependent Adults $A c t$, and two draft statutes, one proposed by the Saskatchewan Law Reform Commission (1981a) and the other by Paul McLaughlin (1979).

\section{Matters to Come Within the Guardian's Authority:}

Under the Alberta Act and the two draft statutes, certain significant personal matters may be made subject to the guardian's decision-making power at the discretion of the court, on the evidence received: where and with whom the person shall live, work situations, vocational and educational programs, social activities, applications for licences and other consents required by law, suit for or defence of legal actions, consent to necessary health care, day-to-day decisions about diet and dress, and control of dangerous behaviour.

The draft Saskatchewan Act further specifies that a court order would be required for the guardian to exercise authority with respect to consent to involuntary committal under the Mental Health Act, an inter vivos transplant, sterilization except for some present or inevitable disease, therapeutic abortion except in a life- or healthendangering situation ${ }^{1}$, termination of the ward's parental rights, and interference with the ward's religious practices which threaten the ward's life or estate. (Law Reform Commission of Saskatchewan, 1981a,

\section{p. 17-18).}

Specifying certain types of decisions for which judicial consent would be required is the approach taken at common law in the United States, at least with respect to medical decisions. In the case of Superintendent of Belchertown State School v. Saikewicz, 370 N.E. $2 d 417$ (Mass. Sup. Ct., 1977). the court ruled that all decisions on removal of life support systems or continuation of life-prolonging treatment for incompetent persons and minors must go before the Probate Court. The reasoning in that case stressed that the court is the most appropriate body to engage in the exercise of determining the person's preferences in so far as that is possible. Joseph Saikewicz was a 67 year-old profoundly retarded man who was suffering from acute leukemia. Chemotherapy treatment would involve considerable pain and very serious complications. and the chances of remission were only 30 to $50 \%$. Because Saikewicz was "a person with disability incapable of giving informed consent to treatment" (p. 419), a court decision was required. It was decided that if Saikewicz had been competent, he would not have chosen to undergo the treatment, and so no chemotherapy was administered. He died without pain or discomfort as a result of bronchial pneumonia, a complication of the leukemia.

The Court recognized that where the person is unable to communicate his/her wishes, and may not totally comprehend the na-

\section{FOOTNOTE}

1. This is a strange statement because danger to life of health of the mother is the only lawful condition under which an abortion may be performed in Canada (Criminal Code of Canada). R.S.C. 1970, c. C-34, s. 251). Another question which arises in relation to this issue is, if a therapeutic abortion committee certities an abortion under 5, 251 of the Criminal Code, can consent be lawfully refused by either the court or a guardian? 
ture of the situation or the consequences of treatment (or lack of it), the attempt to determine his/her preference will be an exercise in speculation. Nevertheless, the standard should be what the incompetent person would do, not what a hypothetical "reasonable person" would do.

The Ontario Court of Appeal, in the case of Reibl v. Hughes (1978), 89 D.L.R. (3d) 112, recommended a similar standard for informed consent. The court said the best interests of the person were to be judged from the standpoint of the particular person's circumstances, that is, the reasonable person in the plaintiff's shoes. This type of combined objective-subjective standard might apply to circumstances in which another person is called upon to substitute his/ her decision for that of the subject of the medical procedure.

The court process required in Saikewicz may to too slow and cumbersome for most decisions that must be made in hospital intensive-care units (Curran, 1978). Curran also thinks that those who had to make the decision to discontinue life-prolonging treatment in the case of Karen Ann Quinlan, i.e. the doctors, family members, and hospital ethics committee, were adequate substitute decision-makers and should be entrusted with Saikewicz-like situations as well.

One of the major concerns in guardianship law is that guardianship not be used as a mechanism for circumventing legal consent requirements to allow a parent to impose his/her will on an unwilling son or daughter. In the case of Eve (1979), 10 R.F. L. (2d) 317 (trial judgment); (1980), 115 D.L.R. (3d) 283 (Appeal judgments), the mother of a 23-year-old mildly retarded woman sought to have herself appointed as the woman's guardian in order to legally authorize her daughter's sterilization. The trial judge and one appeal judge said the court could not invoke its jurisdiction to authorize the mother's consent, but two appellate justices disagreed. The matter is presently un- der appeal to the Supreme Court of Canada.

Another example of problems with surrogate decision-making powers occurred in the Phillip Becker case is California. Phillip's biological parents refused to consent to heart surgery which was necessary if Phillip was to avoid a slow and painful death. While the lower courts refused to interfere with the parents' autonomy, the California Superior Court found itself able to appoint another couple as Phillip's guardians because they were Phillip's psychological parents, having been very involved with him at the institution to which his biological parents had committed him early in his life. However, the quality of judicial reasoning in the Becker decisions has been severely criticized as unprincipled and emotional, not contributing to the development of our understanding of the difficult issues involved in these life-and-death matters at all (Annas, 1982).

Despite the ambiguity of judicial reasoning in Eve and the criticisms in the Becker case, I would recommend that certain crucial decisions should not be left to the discretion of the guardian until some firm guidelines have been developed by the courts in Canada as to how these important matters are to be decided. The concerns about effects of delay in medical life-anddeath emergency situations can be accommodated by appropriate modifications in the common law.

\section{Principles By Which Decisions Are To Be Made:}

General guides are needed in addition to limitations as to subject matter of the decision. The Alberta Act provides that the guardian's authority be exercised (a) in the best interests of the dependent adult; (b) in such a way as to encourage the adult to become capable of caring for himself and of making reasonable judgments in matters relating to his person; and (c) in the least restrictive manner possible. (s. 11 as am.). 
McLaughlin (1979) would add the following duties to the obligation to observe the best interests of the ward: (a) to act as a vigorous lay advocate; (b) to encourage integration into normal community life; (c) to provide reasonable protection for the physical integrity and personal rights of the person from neglect, abuse and exploitation; and (d) to take into account the wishes and opinions of the person subject to the order (McLaughlin, 1979, s. 8 (1)).

The final requirement is a crucial addition to the other guidelines because it is an attempt to ensure that the guardian will recognize the unique personality of his ward, and encourage the ward to express his/her individuality.

None of the statutes discussed here makes recommendations about setting priorities among the various guidelines offered. That is, is it more important to encourage integration into the community than it is to respect the wishes of the ward, for example? If the ward expresses a strong desire to live in a residential setting which appears risky or potentially exploitative to the guardian, whose judgment should prevail? Again, it may be preferable to have such conflicts referred to the courts for guidance, initially, as the subtleties of the facts of each case are best analyzed by a judge. After a body of jurisprudence has developed, it may be possible to set these priorities in a statute.

Six procedural principles developed by Dickens (1980) in the context of surrogate medical consent could provide valuable guidance to the courts and to guardians. These are:

(a) ... [T] he guardian of an incompetent person has legal responsibilities, not just legal powers.

(b) Legal powers must be used primarily to discharge responsibilities and never to violate responsibilities.

(c) Where the incompetent person has evolved a personality, the responsibility of the guardian is to exercise his power to serve the dependent person's known or presumed wishes, and never contrary to or inconsistently with such wishes.

(d) Where the incompetent person has never been competent, the guardian must nevertheless conscientiously strive to serve the dependent's personal preferences.

(e) Where the incompetent person had never evolved a personality, the responsibility of the guardian is to exercise his power primarily in the objectively estab. lished best interests of that person, and never contrary to or inconsistently with such interests.

(f) The guardian must never apply his power to serve his own interests or wishes when these are inconsistent with the wishes or interests of the dependent person." (p. 52)

\section{Values in Guardianship Decision-Making:}

Even where the content of a guardian's duties would be limited as suggested above, and his/her authority guided by the principles described, there will still be considerable scope for discretion in decision-making, particularly if a public agency provides the guardianship service. The most careful efforts of a guardian to ascertain the person's wishes may come to naught in the majority of cases for the simple reason that many retarded people have extremely limited experience with the alternatives that may be open to them, and thus have no bases upon which to make a choice. While the first obligation of the guardian should be to familiarize the ward with some options, there will nevertheless be room for influence and ultimate control.

Guidelines which emphasize "objectively determined best interests" would leave guardianship law open to the same criticisms as have been developed in the child welfare field. There, the best interests test was first introduced to overcome strong presumtions in favour of natural parents when custody was in issue, to allow the 
courts to place a child where he/she would benefit most. But the standard has been transformed over the years so that influential experts now claim that it stands for almost the opposite proposition, i.e. that the best interests of the child will be served by the courts and social agencies respecting parental autonomy and refraining from intervening in family life. This move from favouring the welfare of the child back to parental rights in North America has been called "the neo-conservative response of the liberals to their failure to improve society" by Dickens (1981). Put another way, the policy shift has coincided with a shift in prevailing values. It has not occurred by accident.

Whatever position one might favour in the best interests debate, at least there is an opportunity to speak out and to attempt to influence opinion in either direction. If those decisions were made within a public agency which was not obligated to reveal its reasons or guiding considerations, such a shift in policy could occur quickly and without any appreciable outside knowlege or influence. Values such as normalization, use of community resources, and maximum integration into society should be officially adopted as policy of a public guardian-ship agency. The advice of an advisory committee of consumers, advocates, and service providers should be sought as well as broad public comment and input through wide dissemination of the guidelines. Such an open process is an essential safeguard for a public guardianship system.

\section{SUMMARY OF \\ RECOMMENDATIONS}

1. Ontario should repeal The Mental Incompetency $A c t$ and replace it with a statute to ensure that all persons who absolutely require involuntary guardianship receive the assistance of a guardian. The powers and responsibilities of the guardian should be specifically defined and clearly limited. Property management can be dealt with either in the same statute or in another one.

2. Criteria for determining who will be subject to guardianship should be functionally defined to ensure that only people who truly cannot make their own choices are imposed upon. Eligibility criteria should initially be very restrictive and should be reviewed after three to five years' experience.

3. Procedural protections must include adequate notice, the right to be present and to be represented by counsel, and the right to disclosure of medical assessments, at a minimum. Further procedural protections should be considered when a statute is drafted.

4. The statute should allow for partial, time-limited guardianship as well as plenary guardianship. A presumption in favour of the former should be incorporated.

5. Options for implementation of an effective system include: (a) individual, private guardians, funded by the province where necessary (akin to a Legal Aid system); (b) a private agency with professional guardians, funded by the province on a purchase-of-service basis; and (c) a public agency operating under the auspices of a government Ministry, such as the Official Guardian's Office, or the Ombudsman's office, but not Health or Community and Social Services, to avoid conflicts of interests.

6. Whichever system is chosen, clear accountability and monitoring mechanisms and procedural safeguards should be instituted to maintain a strong link between the supervisory role of the court and the decision-making powers of individual guardians. Each personal guardian should be obliged to file a complete plan for performance of his/her duties with respect to each person for whom he/she is responsible, comparable in concept to the scheme for estate management now required under the Act. These plans should be subject to the approval and supervision of the court. This assessment and supervisory function might be best performed by a Family Court or an ad- 
ministrative tribunal specially created for that purpose, subject to judicial review and appeals to the courts. Such forums provide more opportunity for decision-makers to develop the expertise and sensitive appreciation for the needs of people under guardianship orders.
7. An empirical evaluation system should be built into the implementation plan to systematically collect data on the numbers and types of people who are placed under guardianship orders, the costs of the program, and the effects of guardianship on people's lives. These data should be used to assess and alter the system in five years' time.

\section{RÉSUMÉ}

Compte tenu qu'on nombre croissant de déficients mentaux quittent les institutions pour vivre dans la communauté, on doit prévoir une forme adéquate de garde légale. Les lois existantes de gardiennage ont été critiquées parce qu'elles manquent de flexibilité et qu'elles insistent plus sur la façon de gérer la propriété que sur le support personnel. Le rôle essentiel du responsable de la garde devrait être de favoriser les meilleurs intérêts de l'individu handicapé tout en respectant ses préférences. L'auteur discute de certains principes de prise de décision concernant la garde dont les aspects valoriels et les priorités. Certaines réformes nécessaires pour établir un programme équilibré de gardiennage devraient inclure l'elaboration de lignes de conduite clairement définies pour imposer la garde; on aborde aussi le problème de l'évaluation de la responsabilité et d'une procédure de base pouvant rendre justice.

\section{REFERENCES:}

Annas, G.J. A wonderful case and an irrational tragedy: The Phillip Becker case continues. The Hastings Centre Report. 1982, 25-26.

Curran, W.J. The Saikewicz decision. New England Journal of Medicine, 1978, 298 (8), 499.

Dickens, B.M. The role of the family in surrogate medical consent. Health Law in Canada, 1980 , 49-52.

Dickens, B.M. The modern function and limits of parental rights. Law Quarterly Review: 1981, 97. 462.

Dussault, W.L.E. Guardianship and limited guardianship in Washington state: applications for mentally retarded citizens, Gonzaga Law Review. $1978,13,585-624$.

Hodgson, R.J. Guardianship of mentally retarded persons: three approaches to a long neglected problem. Albany Law Review, 1973, 37, 407.

International League of Societies for the Mentally Handicapped Symposium on guardianship of the mentally retarded: Conclusions. Brussels. Belgium, 1969

McLaughlin, P. Guardianship of the Person. Downsview, Ontario: National Institute on Mental Retardation, 1979.

Mitchell, A.M. The objects of our wisdom and our co- crcion: involuntary guardianship for incompetents. Southern California Law Review, 1979. 52, 1405.

Ontario Association for the Mentally Retarded. Posttions on Social Issues, 1980. Toronto, Ontario.

Saskatchewan Law Reform Commission. Tentative Proposals for a Guardianship Act. Part l: Personal Guardianship. Saskatoon, 1981 .

Saskatchewan Law Reform Commission. Tentative Proposals for a Compulsory Mental Health Care Act. Saskatoon, 1981 b.

Sherman, R.B. Guardianship: Time for a reassessment. Fordham Law Review; 1980, 49, 350378.

Sommerville, M.A. Consent to Medical Care: A Study Paper. Ottawa: Law Reform Commission of Canada, 1979.

United Nations. Declaration on the Rights of Mentally Retanded Persons. New York: 1971.

Vickens, D, Guardianship, Déficience Mentale/Mental Retardation, 1980, 30 (4), 14-17.

Weir, J.T. Mental incompetency applications. Special Lectures of the Law Society of Upper Canada. $1963,13$.

Wolfensberger, W. A Multi-Component Advocacy/Protection Schema, Downsview, Ontario: Canadian Association for the Mentally Retarded. Monograph, 1977. 